\title{
1. What judging and legal reasoning have been
}

One way of understanding judging, and the reasoning associated with it, is to ask what it has been. In posing this question with respect to law within what might be called the Western Tradition - that is the tradition that originated in Europe before spreading via colonialism to other parts of the world - one is faced with two sub-traditions, namely the civil law and the common law. The history of the common law in England is not one associated with Roman law texts or with Romano-Canonical procedure and so there are important differences with respect to the reasoning methods associated with the two traditions. However, particularly from the 19th century, there have also been interactions. Some have argued that although Roman law and common law had no genealogical connection, Roman jurists and common lawyers share some of the same casuistic (or 'bottom up') methods. Jurists from both legal systems tended and tend to reason from practical cases. Looking at what legal reasoning has been in the civil law is, therefore, of some relevance.

\subsection{ROMAN LEGAL REASONING}

The starting point for reasoning for much of Roman law's history was whether or not a person had a legal action (actio).

Digest of Justinian Book 9 Title 2 (translation Geoffrey Samuel)

52. ALFENUS, Digest, book $2 \ldots$ 2. On Capitoline hill mules were pulling two loaded wagons; the drivers of the first wagon which had tilted up were supporting it so as to make it easier for the mules to pull it; however while doing this the first cart started to roll backwards and when the drivers, who had been between the two wagons, had got out of the way, the rear cart was hit by the one in front and moved back and crushed someone or other's slave boy. The owner of the slave boy asked me against whom he should claim. I replied that the law was to be found in the facts of the case (respondi in causa ius esse positum). For if the drivers who were supporting the wagon got themselves out of the way on their own accord and it was as a result of this fact that the mules were not able to hold the wagon and were themselves dragged back by the load, then no 
action could be brought against the owner of the mules. However with respect to the men who were holding up the tilted wagon a claim under the lex Aquilia could be brought; for it is no less the doing of damage he who voluntarily lets go of something he is holding up so that it hits something; for example if someone who steers an ass does not restrain it, he would do wrongful damage in the same way as if he had discharged a spear or anything else from his hand. But if the mules behaved in the way they did because they were frightened by something, and the drivers left the wagon fearing they would be crushed, while no action could be brought against the men, an action could be brought against the owner of the mules. However if neither mules nor men were the cause, but the mules could not hold up the weight, or while trying slipped and fell and the wagon went backwards and the men had been unable to bear the weight of it when the wagon tilted over, neither the owner of the mules nor the men would be open to an action. What is indeed certain, whatever the situation in this affair, is that no claim could be made against the owner of the mules pulling the wagon behind, for they did not go back on their own accord but because they were hit and pushed backwards.

One might note here how the jurist reasons 'bottom up' so to speak. In order to determine whether the claimant has an action one must examine in detail the circumstances: the law is to be found in the facts (in causa ius esse positum). The Romans thus placed great emphasis on factual examples; they moved from one factual situation to another. The jurists also frequently quoted other jurists, either in agreeing with them or perhaps suggesting a different result from the facts.

\section{Digest of Justinian Book 8 Title 5 (translation Geoffrey Samuel)}

8. ULPIAN, Edict, book $17 \ldots$ 5. Aristo says in an opinion given to Cerellius Vitalis that he does not think that smoke can in law be discharged from a cheese workshop on to the buildings above it, unless the buildings are subject to a servitude of such a kind and this is admitted. The same author says that it is not legal for water or anything else to be discharged from the building above to the one below: as a man is lawfully able to do things in his own premises only when he discharges nothing onto those of another; now smoke like water is something that can be discharged. An action is given in this case against the upper owner as well as the lower owner not to act in this way. He says finally that Alfensus writes that an action can be brought in which it is asserted that a person cannot lawfully cut stone on his own land in such a way that fragments fall onto my land. Aristo thus says that a person who has hired a cheese workshop from the town of Minturnæ can be prevented from discharging smoke by the owner of the upper floor, but he would have an action against Minturnæ on the contract of hire; he adds that one can bring an action against the person who discharges the smoke in saying that he has no lawful authority (ius ei non esse fumum immittere) to discharge smoke. It must follow, in contrast, that one can bring an action to assert that he has lawful authority to discharge smoke (ius esse fumum immittere); this also appears to have Aristo's approval. And indeed an interdict uti 
possidetis can be obtained if one is prevented from doing what he wants on his own land. 6. A doubt is raised by Pomponius in his Readings (Lectiones 41) as to whether one can bring an action to assert lawful or non-lawful discharge of smoke that is not serious, for example smoke from a hearth. And the major view is that one cannot bring an action, just as one cannot bring an action to assert that it is lawful to light a fire or sit down or to wash on one's own land.

Again one can see how important the legal action (actio) or (to use today's language, remedy) was in Roman legal analysis. This is the 'institutional' viewpoint from which the facts are set out and analysed. One can thus describe the method as being remedy orientated. The jurists are not starting out by quoting 'the law' in terms of some pre-existing set or rules of 'rights'. They are basically asking whether or not the claimant has an action. However the Romans did write introductory textbooks (institutiones) for students and these texts differ from the great practitioner work of the Digest of Justinian.

\section{Gaius, Institutes, Book IV (translation Geoffrey Samuel)}

1. It remains to speak of actions. And if we ask what genera of actions there are, it seems in truth to be two, in rem and in personam. For those who have spoken of four in counting sponsionum in the class of genera they have treated a species of action as if it is generic. 2. An action in personam is one where we sue someone obligated to us either in contract (ex contractu) or in delict (ex delicto), that is where we claim that he ought 'to convey (dare), to do (facere) or to perform (praestare)' something. 3. An action in rem is one where we claim either a corporeal thing to be ours or some ius [in a thing], as for instance the ius of using or usufruct, going over, driving over or conducting water over land or of raising the height of a building or of having an unobstructed view. A negative opposing action [in rem] is available to the adversary. 4. And so having described actions, it is clear that it is not possible for us to claim our thing from another in the following way: 'if it appears it ought to be conveyed'. For what is ours (quod nostrum est) cannot be conveyed to us since of course to be conveyed is to be understood as what is given to us is made ours but a thing which is already ours cannot be made more ours. It is true that one's hatred of thieves, in order to multiply the actions for which they are liable, it has become accepted that, in addition to the penalty of double or quadruple, thieves are even liable for the recovery of a thing set out in this way: 'if it appears that they ought to convey', although this action for what is ours is available against them as well. 5. Actions in rem are, on the one hand, called vindications (vindicationes); actions in personam, on the other hand, whereby we claim that someone ought to convey or do, are called condictiones. 6 . Sometimes we sue in order only to obtain our thing (res), in others only to obtain a penalty, and in others to obtain our thing and a penalty. 7 . We sue only for a thing in for example in actions founded on a contract (ex contractu). 8. We sue for a penalty in actions for theft and insult and, 
according to some, for the action for aggravated robbery; for in this situation both the vindicatio and the condictio are open to us....

Here, again, one can see just how important actions were to the Roman jurists up to the end of the Classical period (middle of the 3rd century AD). However this text is far more general and begins to read a little like a book of rules, although Gaius probably did not regard his Institutes as being about stating rules (regulae). One particular, important technique employed in this textbook should be noted: namely the importance of classification according to genus and species. Some regard this development of classification techniques (which started a century before Gaius) as the foundation of a legal 'science'. As for the whole of law, Gaius classified it in the following way:

\section{Gaius, Institutes, Book I}

8. All law that we use relates either to persons (persona), or to things (res) or to actions (actiones).

This is basically the classification scheme that remains dominant in modern European law, although the category of actions has been replaced by 'obligations'. It is one of the first examples of a structural approach whose coherence is such that the scheme amounts to a system (see 5.5).

\subsection{MEDIEVAL JURISTS}

At the end of the Roman Empire a huge collection of Roman law, compiled under the authority of the emperor Justinian, was published in 533 AD. The central part of this Corpus Iuris Civilis was the Digest, which consisted of extracts from the many law books which had been written largely from the century before Christ up until the 3rd century AD. This Digest collection of Roman law was rediscovered in the 11th century and became the basis of law teaching in Italian and, later, French universities. The later medieval jurists wrote long commentaries on every part of the Corpus Iuris. 
Bartolus, Interpretum luris Civilis Coryphaei, in Ius Universum Civile, Commentaria, Basileae, Froben, 1562, p 463 (translation Geoffrey Samuel)

When the owner of a lower tenement lights a fire in the course of normal family life this is, then, lawful and he will not be held liable if the smoke ascends unless he does it with a wrongful intent. And in the same way if the owner of the upper tenement allows water to flow, for his water time piece, he will not be liable if the water descends unless he was doing it with wrongful intent. But if the owner of the lower tenement was running a shop or an inn, where he was continually having a fire which generated a large amount of smoke, this is not lawful (non licet) according to him [Aristo]. In the same way if the owner of the upper tenement allows water to flow beyond the normal amount this is unlawful he [Aristo] says.

This commentary is taken from a late medieval Roman law specialist who was commenting upon the Ulpian text set out earlier (see 1.1). What is important to notice here is that Bartolus (1313-1357) is adopting a different viewpoint. He is not approaching the problem in terms of whether or not an action or remedy is available; he is, instead, analysing the facts from the position of whether or not it is lawful to make smoke. He also introduces into the analysis something not really mentioned by Ulpian, namely fault. Ulpian does not discuss in the actual cheese shop text what the position would be if someone made smoke in order intentionally to annoy a neighbour. However elsewhere in the Digest of Roman law there are texts dealing with damage wrongfully caused and, of course, Bartolus, who knew by heart the whole of Roman law, would be well aware of these other texts. Thus he is in effect bringing together in one text what the Romans had dealt with in a mass of separate texts. Moreover Bartolus is applying a particular method called a dialectical analysis. This is where a problem and (or) a text is analysed in terms of an either/or (aut ... aut in Latin) scheme. It is in essence the basis of what today we call an algorithm, which can be set out as shown in Figure 1.1.

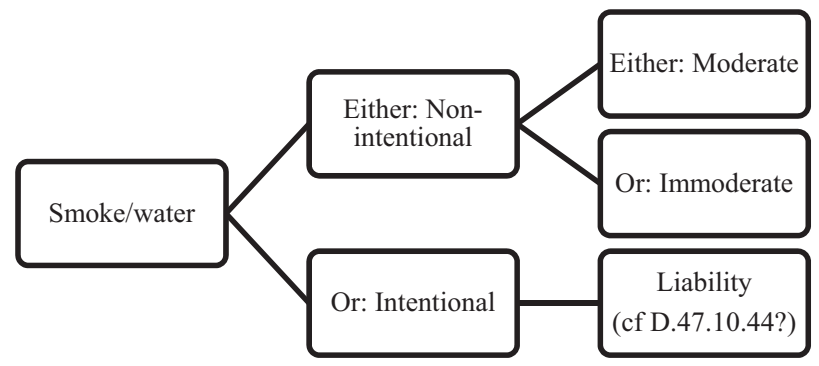

Figure 1.1 Bartolus and the cheese shop 
One important characteristic of this method is the exclusion of any third way.

\section{Ian Maclean, Interpretation and Meaning in the Renaissance, Cambridge University Press, 1992, p 39 (footnotes omitted)}

... Renaissance jurisprudence is to be distinguished from medicine by its predilection for the species contraria immediata of opposition; persons are masculine or feminine, guilty or not guilty, persons, things and actions are in a given category or are not, words are used literally or figuratively; there is no third term or coexistence of possibilities. The authoritative and logical summaries of points in commentary and monograph encourage this decisiveness, which lawyers see as a distinguishing mark of their art.

Such a scholastic approach might seem somewhat pedantic today, but the development of this method was in its time revolutionary.

\section{Walter Ullmann, Law and Politics in the Middle Ages, Sources of Legal History, 1975, p 87}

The scholastic method was dialectics brought to perfection: it was a method by which numerous contradictions in the Corpus of law were to be solved by the mental operation of a distinction and if necessary subdistinctions and subdivisions, until a common denominator of the contradictory passages could be found. This resulted in the complicated and finely woven texture of numerous distinctions which makes it so difficult for the modern reader to penetrate into the matrix of medieval governmental ideas profitably. Within civilian jurisprudence the distinctive feature of this method was the triad consisting of the positio (one standpoint or one interpretation or one legal enactment) contradicted by the oppositio and the solutio which deduced the elements which were common to both the positio and oppositio. It was this method which the civilian (and canonistic) glossators practised in the twelfth century.

This is an excellent description of the dialectical (scholastic) method, although it might be more accurate to say that one induced (rather than deduced) a common denominator. The method has shaped legal thinking and resulted in three particular approaches associated with this casuistic (distinctions and sub-distinctions) approach.

\section{James Gordley, The Jurists: A Critical History, Oxford University Press, 2013, p 277 (footnotes omitted)}

The problem of applying authoritative texts to situations that they do not expressly cover is one that modern lawyers face as well. The medieval jurists 
found ways of doing so that modern lawyers still use. One is to generalize a text that deals with one situation so that it can be applied to others. Another is to limit a text framed in general terms by distinguishing situations to which it should be applied from those to which it should not. The third way is to move directly and by analogy from the situations dealt with expressly in the texts to a different situation. Modern jurists proceed in these ways when they apply a code, a statute, or a precedent. Since the task is similar, this similarity is not surprising. Beginning with an authoritative text, one can move up, down or sideways. These are the only directions in which one can move.

A good example of the second method outlined by Professor Gordley is to be found in the case of Birmingham CC v Oakley (2001) (see 2.4). These outlined methods are, then, still in use today but, as Gordley later points out, modern jurists use other methods as well (Gordley, 2013, 42).

\subsection{LATER JURISTS}

In the 16th century there were further changes in the style and method of legal reasoning.

\section{Geoffrey Samuel, Legal Reasoning and Argumentation, in James D Wright (editor-in-chief), International Encyclopedia of the Social \& Behavioral Sciences, 2nd edition, 2015, Vol 13, Elsevier, 776, pp 778-779}

... [a] though the Roman texts, and the practical problems discussed by the Roman jurists, were large and extensive, they did not cover everything and so the medieval jurists were faced with the problem of applying these texts to new situations. They did this in a largely casuistic way; they started out at the level of fact - persons and things - and developed Roman law notions using induction and analogy. Thus they might generalise a text by way of induction so that the rule (regula) could be applied to the new situation or they might take a particular factual problem discussed in the Roman texts and apply it by way of analogy (Gordley, 2013, 33-45). Equally they limited the application of a text or a rule by the use of distinctions and dialectical oppositions (Ullmann, 1975, 87). In doing this the later medieval jurists - the Commentators - fashioned what might be termed an algorithmic approach to legal reasoning and problem-solving (aut ... aut: either ... or)....

When one looks forwards from the medieval jurists a very different reasoning model gradually emerges. The change came in the 16th century with a school of French jurists known as the Humanists who developed a new approach towards the Roman texts (see generally Kelley, 1970). The humanists sought, on the basis of Roman classical law, to establish law as a science through which it could be explained clearly and systematically (Stein, 1999, 79-82). They wanted to cut through all the old 'pedantic' glosses and casuistic reasoning of the past to get back to the original Roman texts and intentions of the authors who wrote 
them - so that the law could be perceived as a coherent whole. The emphasis henceforth was no longer to be on the particularities of the case and its analysis through dialectical distinctions and analogies but on what might be called the 'architecture' of the legal system - on how it fitted together as an interrelating systematic whole (Thireau, 2001, 232-238; Villey, 2006, 454-487).

Despite the fact that the humanist project had, at the time, little influence on legal practice or the methods employed by practitioners - the Mos Italicus (late medieval Italian methods) continued to dominate practice right into the 17th century (Jones, 1940, 34-35) - the longer term effect of this humanist revolution on legal reasoning proved immense. During the 17th and 18th centuries attention turned away from the kind of casuistic methods that characterised the Roman and medieval jurists towards a deductive and then axiomatic approach to reasoning. The authority of texts, which was the basic epistemological paradigm of the medieval age, gave way to a new paradigm, namely the authority of coherence. Thanks to jurists who were also mathematicians, such as Wilhelm Leibniz (1646-1716) and Christian Wolff (1679-1754), legal reasoning became associated with geometry (mos geometricus); solutions to legal cases were, accordingly, to be solved uniquely by the use of deductive logic (Gordley, 2013, 165-194; Champeil-Desplats, 2014, 60-63). The result was a complete change in the nature and style of law books. The dialectical method of division, distinction, induction and analogy, rooted in practical case examples, was replaced by a highly systematised set of ever more abstract legal propositions that no longer followed the order set out in the main source of Roman law itself, namely the Digest. They adopted the style and structure which characterised the Institutes. Thus, in France, the jurist Jean Domat (1625-1696) rearranged Roman law in its 'natural order' so that the Roman law was to be learned and applied, not through the reading and application of the original texts, but through a set of principles. The great advantage that this textbook reform brought to law - an advantage for practitioners as well as students - was that the law (in effect Roman law) became very much easier to read and absorb (Gordley, 2013, 145). $\ldots$

Sir Henry Maine said that the 16th and 17th centuries were a great juridical era but that reform of the law consisted of reform of the law books (Maine, 1890, 363). What did he mean? The medieval jurists, in their commentaries on the Digest, religiously followed the order of this Roman work, which, unlike the Institutes, was not based on any coherent plan. However the Humanist jurist Hugues Doneau (1527-1591) rethought the whole of the Digest in the new way.

\section{Hugues Doneau, Commentarii de Jure Civili, 6th German re-edition (1822), Book 1, Chapter 1 (first published 1596) (translation Geoffrey Samuel)}

$\S 2$. Why I so feel the need to warn you at this early stage [about the order and arrangement of the Digesf] I will set out briefly. With the civil law, which is the part of the law which assigns each person their rights, prescribes as it were 
things in two parts, and it is this order upon which we will focus; what rights each person is recognised as having, and the rationality of this recognition, in order that they can be dealt with later in much more depth in their own section. There is nothing perverse in the Digest and what relates to each of the two parts will be collected together and explained. For the right that each person has is partly in the person himself and partly in an external thing. However the rational determination of our right involves examining legal proceedings. How, I ask, can this right and rational way of knowing our rights be contrary to the way its various parts are instituted by the compilers? This is because you find set out the rights of personal status of some people in a few words followed by the division of things, and then is set out that part which is concerned with judges, jurisdiction, the right to summon to court, and things preceding the judgment, and the stages up to the decision. Why? So that our judgments are properly known. And from where actions, as much in rem as in personam, are immediately afterwards the subject of treatment. Therefore from judgments our right is obtained through rational reasoning, informing us clearly beforehand what is our right, what we can deduce from a judgment, what they should have taught us. Instituting a claim, given that everything is a matter of our right, our debts, we will understand beforehand what these are. And so then knowledge of what each person's right is, is something that by its very nature ought to precede any claim; this being known how, it might be asked, is the means of obtaining it.

$\S 3$. Does one go about explaining each part one by one? Indeed, so that each part of the limbs of the body are exposed; but only the limbs are discoverable, often scattered around and distant from the head, rather than the body itself. First, the question of rights regarding the status of persons is raised and what fixed rights that almost every person he himself has; these are life (vita), bodily integrity (corporis incolumitas), liberty (libertas) and reputation (existimatio)....

Doneau set out his commentaries according to the plan of the Institutes of Justinian (that is the plan inherited from the Institutes of Gaius) and from the position, not of different kinds of action (actio), but of 'rights' (ius). He rethought Roman law from the position, first, of what rights each person has as a person (law of persons) and, secondly, what rights each person has in external things (law of things). With regard to the former the law of persons - he said that these rights were life, bodily integrity, liberty and reputation. With regard to the latter - the law of things - he saw these rights as being divided into two kinds, namely 'what is ours' (law of property) and 'what is owed to us' (law of obligations). He thus established the legal plan to be found underpinning all of the modern civil codes; private law is sub-divided into persons, property and obligations. Doneau's use of the institutional plan was taken up by other writers, in particular the 18th-century French jurist - said to be the father of the French Code civil - Robert Pothier (1699-1772). 
Robert Joseph Pothier, Pandectis Justinianeis in Novum Ordinem Redactis, De Diversis Regulis Juris Antiqui, Volume I, Pisis, 1825 edition, pp 5-6 (translation Geoffrey Samuel)

This work will be divided into five parts.

In the first part are offered the general rules of law either natural or civil, that is to say which cannot be said to be special to a particular part of the law, and then those which belong to the leading notions of the laws and also their interpretation.

The second part will contain those regarding persons.

The third regarding things.

The fourth regarding actions, or judgments, the order of judgments etc.

These three objects are the universal objects of private law, For 'all law that we use pertains to persons, to things or to actions' (J.1.2.12).

The fifth part contains public law.

To return to Doneau, one might note also how he was the first to identify what today we would call 'human rights'. As for the law of actions, this he regarded as something separate from substantive law and which belonged to the law of procedure. Doneau, in short, is the true grandfather of the modern civil law. Doneau did not, however, reduce the content of the Digest to an Institutes-length book. Quite the opposite since his Commentarii runs to 28 volumes. It was the French jurist Jean Domat (1625-1696) who reduced Roman law to a somewhat shorter work.

\section{J Domat, Les loix civiles dans leur ordre naturel (2nd ed, 1695; nouvelle édition 1735) (with references), Preface (translation Geoffrey Samuel)}

It seems very strange that the Civil Laws, whose usage is so necessary, be so little known, and that being nearly all about rules of equity, knowledge of which is to us natural, of which the study ought to be equally easy and agreeable, are so difficult and so painstaking.

However it must be recognised that the manner by which these laws are collected in the Books of Roman Law, which are the only source of these laws, makes it not at all easy to understand. And it is this which, among those whose profession obliges them to know these laws, results in some who do not know them, and that no one can become well versed except by a long and painstaking study.

Domat achieved this reduction by re-presenting Roman law as a series of easily understandable propositions. Take for example the cheese shop problem discussed by Ulpian (D.8.5.8.5: above 1.1). 


\section{J Domat, Les loix civiles dans leur ordre naturel (2nd ed, 1695; nouvelle édition 1735) (with references), First Part, Book I, Title XII, Section XII (translation Geoffrey Samuel)}

$\mathrm{X}$. Works and other things that each person can do or have in his own house and which spread into the apartments of those who have a part of the same building, or neighbour's houses, or unpleasant smells such as from tanners and dyers, and other different discomforts a neighbour can cause to another, must be suffered if a servitude is established. And if there is no servitude, the discomfort will be either suffered or prevented, according to the quality of the area, and the discomforts itself, and according to the rules of the police or of usage, if there are any, that will apply to the situation (D.8.5).

Gone is the casuistic case approach based upon the availability of a legal action; law is now a matter of abstract principles which read more like extracts from the final title of the Digest, namely de regulis iuris (on rules of law) (D.50.17).

\subsection{LEGAL REASONING IN THE LATER CIVIL LAW}

This reduction to a set of regulae had an important effect on legal reasoning in that the propositions came to be regarded as 'axioms' (axiomata).

\section{Joham Gottlieb Heineccius, Elementa Juris Civilis Secundum Ordinem}

Pandectarum, 1785 edition, Book 9, Title 2, Lex Aquilia (translation Geoffrey Samuel)

§183 From these definitions are the following axioms: I. Whenever there is malice or negligence and damage there is an action based on the lex Aquilia. II. This statute requires that through our physical things being damaged by a physical act our patrimony is diminished.

$\S 184$ Since, then, it is at least negligence or malice that the lex Aquilia requires, the consequence is 1) that any negligence, even the slightest is sufficient (D.9.2.44pr). 2) Anyone intervening is obliged to show diligence otherwise he commits wrongful damage whether directly or by omission (D.9.2.8pr). 3) And so this includes inexperience and 4) weakness, if it would arise from inexperience, or from his own weakness if it would be a danger to others (D.9.2.8.1).

$\S 185$ Thence we infer 5) no action is possible against someone not guilty of negligence, such as a madman or a young infant if still baby-like and does not know what he is doing (D.9.2.5.2). 6) in neither case can it be imputed (D.9.2.5.3) and moreover it is not 7) damage to another without wrongfulness occurring from someone who can legally use it. Which at first is moderate and 
irreproachable relating to someone in guardianship, which becomes an aggressive unjust violent force threatening life or danger to one's body which if continued would kill the person in guardianship.

One can compare this text with D.9.2.52.2 (see 1.1). Legal reasoning is no longer about practical cases, but about high-level 'axiomatic' rules. The legal reasoner does not start out from facts but from the rule. The method is one of logical deduction with the judge being considered little more than a 'machine' mechanically applying the law to facts that have been fed to the court. By the 19th century the whole of fault liability had been reduced to a single axiom.

\section{Code civil 1804}

Art 1382 [now art 1240]. Any act whatsoever by a person which causes damage to another obliges the person by whose fault it has occurred to repair it.

Concepts equally lay at the basis of this 'axiomatic' reasoning. For example, in Roman law the whole of the law of property was focused around three basic concepts: ownership (dominium, proprietas), possession (possessio) and rights in another's property (ius). However, as we have seen, the Romans did not reason by starting out from abstract definitions of these concepts, for all definitions are dangerous said a Roman jurist (D.50.17.202) and, anyway, the law was not to be found in abstract rules (D.50.17.1). Indeed, there is no definition of ownership to be found anywhere in the Roman sources. It was the medieval jurist Bartolus (building on the work of earlier medieval jurists) who induced out of all the Roman texts a definition.

\section{Bartolus, In primam Digesti Novi partem Commentaria, ad D.42.2.17.1 nos 4 and 5 (translation Geoffrey Samuel)}

What then is ownership? My reply is that it is the right (ius) in a physical thing of complete disposal unless legislation prohibits it ... Why do I say complete disposal? Because of [C.4.35.21] and because it is differentiated from possession, which is the right to stand on a thing (ius insistendi rei)....

I ask, how many kinds of ownership exist? Some doctor from Orleans, as recounted by that German doctor who held a repetition here yesterday, says there is only one type of ownership. But there are two. And I prove this in referring to I. possessores in fin C. de fundis patrimonialibus lib. 11 [C.11.62.12.1] where it is said that a person who holds land in long title (emphyteuta) is owner. 
And yet another remains owner, that is to say the lessor (concedens) [C.4.66.12]. And if there are two owners there are two forms of ownership because the same ownership cannot be split between two persons as stated in [D.13.6.5.15].

This definition, much later, became an axiom.

\section{Joham Gottlieb Heineccius, Elementa Juris Civilis Secundum Ordinem Pandectarum, 1785, Book 41, 1, De Adquirendo Rerum Domino (translation Geoffrey Samuel)}

§ 161 Ownership is a right in a corporeal thing from which flows the ability to dispose of it and the right to vindicate it, unless statute, agreement or a voluntary will provision opposes it. Where this ability to dispose and to vindicate come together in the same person, so that both can be enjoyed in solidum, this is called FULL ownership; where it is split between two, so that one person's full interest to use of the thing can be vindicated as a right while the other person has the ability to dispose of the thing this is LESS than full ownership (minus plenum). And here UTILE and DIRECTUM are divided.

Despite writing in the early 18 th century, Heineccius cannot escape the influence of the medieval jurists. His distinction between the two types of ownership was not actually to be found in Roman law - although a person who held land under a long lease, although not owner, was finally given an actio in rem (D.6.3.1.1) - but was an invention of the medieval jurists who were trying to apply Roman law to their feudal society. In fact the French jurists of the 17th century abandoned this dichotomy. Consequently by the time of codification there was just a single form of ownership.

\section{Code civil (1804)}

Art. 544 Ownership (la propriété) is the right to enjoy and to dispose of things in the most absolute manner, provided that one does not make a usage prohibited by legislation or by regulations.

One often says that this definition of ownership is Roman in origin. Certainly in spirit it is Roman. But the definition is the result of the reasoning on Roman law by subsequent jurists. It indicates just how important jurists such as Bartolus were in shaping our modern view of the civil law. 
When one turns to possession the Romans did get closer to formulating something of a definition. Or, at least, they formulated certain conditions.

\section{Digest of Justinian Book 41 Title 2}

3. PAUL, Edict, book 54. Possession is possible only of corporeal things. 1. And we obtain possession by physical act (corpore) and intention (animo), not by intention alone or by physical act alone. But when we say physical act and intention are required to obtain possession it is certainly not to be taken to mean that that he who wants to possess an estate must walk around the whole of the land; it is sufficient to enter any part of the estate while having the intention and purpose of possessing the whole of the land up to its boundary.

12. ULPIAN, Edict, book 70 ... 1. Ownership (proprietas) has nothing in common with possession: and thus whosoever brings a vindicatio for the thing is not to be refused the interdict uti possidetis ...

17. ULPIAN, Edict, book $76 \ldots$... There is this difference between ownership (dominium) and possession, ownership nevertheless continues even when he does not wish it, possession however departs when he decides not to possess.

30. PAUL, Sabinus, book 15. Whosoever possesses a building as a whole, is not regarded as possessing the individual things in the building. The same must be said both of a ship and of a cupboard ...

From these basic conditions a later civilian such as Heineccius was able to construct not just a whole deductive model of axioms but one that had the notion of a right (ius) at the basis of the property structure.

\section{Joham Gottlieb Heineccius, Elementa Juris Civilis Secundum Ordinem Pandectarum, 1785, Book 41, Title 2, De Adquirendo vel Amittenda Possessione (translation Geoffrey Samuel)}

§ 197 Having dealt with ownership, possession now follows. To possess is to have, hold or detain for a period of time. And the word is not meant as the place of standing but is meant as I can take over the place of standing. And so POSSESSIO in both its natural and grammatical sense is the bare detention of a thing (nuda rei detentio) without any right in the thing (iure in re). In the civil and legal sense, it is the detention of a corporal thing with the intention (animus) of having it.

§ 198 Who has this intention of having the thing thus has, provided that he believes that no one else is the owner, BONAE FIDE possession. If he does not believe that someone else is not the owner, it is said that he is a MALAE FIDE possessor. Thus non defective possession (NON VITIOSA) is where he possesses without force, stealth or permission of the owner (nec vi, nec clam, nec precario). Defective possession in contrast, is where there is such defectiveness present. Finally who has possession founded upon a just title has just (IUSTA) possession; who does not is said to have unjust (INIUSTA) possession. 
$\S 199$ Thus possession is not a matter of law but fact. And so it seems to be a mistake to say that he who possesses has a real right (ius in re). It is thus a correct observation to say that a division into a right in re and a claim ad rem is not a relevant legal one in respect of possession.

\$200 It is now easy to understand the axioms: I. Possession is acquired by physical act (corpore) and intention (animo) (D.41.2.3.1, 8, 51). II. Intention alone retains possession so that another person will not acquire it (D.41.2.3.7, 5, 30.5). III. Just as in the manner it is acquired, it is ordinarily lost (in the same way) (D.41.2.8, D.50.17.153)...

§ 202 From this same axiom we say 1) proper possession is possible of corporal things, and so 2) if it is of an incorporeal thing it is only quasi possession. 3) Possession applies only to things not to free people (D.41.2.23.2), although possession of people once acquired in good faith can be retained while the question of their freedom is being litigated. 4) One cannot acquire possession of some things, the commerce of men (D.41.2.30.1) for example who are dead and even less possession through them or things which are not in a state of being possessed (D.41.3.3.5).

\$203 Finally from this first axiom it follows that 1) there is no possession of an inheritance even when all the rights to it are transferred unless it is physically taken (D.41.2.23pr, 30.5). 2) Any kind of physical taking will suffice or entering into land, and so neither 3) the whole of the land has to be walked all over (D.41.2.3.1, 48, 2), nor 4) is it unhelpful to see this as a fiction, as if accepting a key when assigning custody (custodia) of a thing (D.41.2.1.21, 51). Intention and title to possession ought to be present, and indeed the title must be true and not a mistaken one (D.41.2.34pr), nor 6) can anyone change for himself the title to possession (D.41.2.3.19, 19pr)....

One thus ends up with a single definition of possession in the form of an axiom.

\section{Code civil 1804}

Art. 2228 Possession is the detention or the enjoyment of a thing or of a right that we hold or that we exercise ourselves or through another who holds it or who exercises it in our name.

One might note, however, that in this French definition one can possess not just a physical thing but also a right. Does this mean that one has the right (ius possessionis) to a right? 


\subsection{LEGAL FORMALISM (DOGMATICS)}

The reasoning methods that attached to Roman law scholarship, particularly from the 16th century onwards, were to lead to what became known as legal formalism or, in the language of the civil law, legal dogmatics ('dogmatic' not being a pejorative expression in this sense).

\section{Véronique Champeil-Desplats, Méthodologies du droit et des sciences du droit, Dalloz, 2014, p 47 (translation Geoffrey Samuel)}

a) Formalism can refer to a mode of definition or to the delimitation of the object of analysis. Stricto sensu, a formalist delimitation of the object 'law' consists in analysing only the positive law and nothing but the positive law, in leaving aside social facts, history, natural law and moral principles. Such an approach is associated with different positivist currents. Strictissimo sensu, the formalist delimitation of the object reduces the analysis, within positive law, to the form and to the structures of legal systems and of norms. The study of the socio-political functions or contents of these norms is, then, left aside ...

One can see the immediate foundation of this legal formalism in the writings of the 17th- and 18th-century jurists such as Heineccius. However, these jurists belonged to what is called the school of natural law, which meant that they considered legal knowledge to be dualistic in its form. There were the positive laws of the region or country and there were higher laws which transcended these positive laws and which, like scientific laws, were part of nature. These two levels could sometimes conflict: an unjust law - that is a law that does not conform to the higher natural law - was said not to be law. This view was abandoned in the 19th century because such 'a dualism could not for a moment be admitted by any philosophy of law' (Jones, 1940, 205). This was because legal 'philosophy required unity and objectivity in its subject matter' and thus it 'must be consistently monistic'. For a 'rule either is or is not law; it cannot at the same time be both' (Jones, 1940, 206). Natural law theory was abandoned in favour of positivism; and along with this 'hardening' of formalism there was a further 'hardening' of reasoning method.

\section{Véronique Champeil-Desplats, Méthodologies du droit et des sciences du droit, Dalloz, 2014, p 48 (translation Geoffrey Samuel)}

f) Formalism can also refer to a certain representation of legal reasoning in general and judicial reasoning in particular. The latter takes the form of a syllogism. Inherited from Aristotelian logic, the syllogism, in its theory, consists in deducing from a general proposition (the major premise), under which is 
subsumed a particular proposition (the minor premise), a conclusion. If the two premise propositions are true, the conclusion is also true: 'All men are mortal' (major premise), Socrates is a man (minor premise), therefore Socrates is mortal (conclusion). On this model, judicial reasoning takes the form of what is said to be a practical syllogism, that is to say one that is geared towards an action. The major premise becomes, then, a general norm: 'all thieves must be punished', the minor premise is a particular proposition expressing a categorised fact ('Socrates is a thief'). From this is logically and mechanically deduced the conclusion: 'Socrates must be punished'.

This said, the 16th-century jurists equally realised, along with the Roman lawyers (see eg D.1.3, D.50.16), that words could be ambiguous. How should expressions be interpreted?

\section{Digest of Justinian}

\section{Book 1 Title 3}

17. CELSUS, Digest, book 26. To know statutes is not a matter of adhering to their words (verba), but of knowing their force and power (vim ac potestatem).

18. CELSUS, Digest, book 29. Benign interpretation should be given to statutes so as to conserve their intention (voluntas).

19. CELSUS, Digest, book 33. When a statute is ambiguous the meaning to be adopted is one which avoids undermining it, above all if the intention (voluntas) of the statute is able to be secured.

24. CELSUS, Digest, book 9. It is against the legal method to make a judgement or give an opinion on one particular part of a statute unless the whole statute has been taken into consideration.

29. PAUL, Sole book on the Lex Cincia. A person acts against a statute who does what the statute forbids; it is a fraud against the statute when one clings to the words (verbis) and evades the meaning (sententiam) of it. Furthermore nobody should be thought to have said what was not motivated by their mind (non mente) ...

\section{Book 33 Title 10}

7. CELSUS, Digest, Book $19 \ldots 2$... For my part I think nobody says what he does not intend (non sentiret), above all if a name be used which is applied to a sole object, for speech is used as our servant.

\section{Book 50 Title 17}

96. MAECIANUS, Fideicommissa, Book 6. In ambiguous speech, one must above all examine the intention (sententia) of the person who has spoken.

These Roman sources provide the starting point for interpretation of legal texts. What emerges from these sources is a tension between words 
(verba) and intention (sententia and mens); and this tension was to be taken up and developed by the later civilian jurists.

\section{Donald Kelley, The Human Measure: Social Thought in the Western Legal Tradition, Harvard University Press, 1990, p 133 (endnotes omitted)}

Put another way, this hermeneutical question concealed $a[n]$ issue crucial to jurisprudence across the centuries, which was whether the construction of laws should be strict or liberal (restrictiva or extensiva). The consensus seems to be on the side of the 'more benign' as against 'rigorous' judgment. 'Interpretation should be not literal [ad literam]', wrote Baldus, 'but rather meaningful [ad sensum], for the sense of the words should prevail.' One should go beyond the literal exposito vocabuli, then, to the 'explanation of the true meaning [ad verum intellectum], understood according to the reason rather than the shell an exterior of the words.' The principle of judicial discretion also involved the complicated question of equity, which (according to an old rule) was the basis for interpreting laws and contracts (fundamentum interpretandi leges et pacta).

Thus three fundamental interpretative approaches grew out of the 16thcentury writings of the civilian jurists. One could focus on the words of the text (verba); on the intention of the legislator (mens legislatoris); or on the rationality of the law as a whole in relation to the specific text (ratio legis) (inspired to some extent by D.1.3.24). We shall see that a fourth approach which was fashioned in more modern times was one that focused on the function of the statute, although this approach overlaps to some extent with the mens legislatoris.

Yet how could these interpretative ideas be reconciled with the mos mathematicus method which underpinned the syllogism?

\section{Véronique Champeil-Desplats, Méthodologies du droit et des sciences du droit, Dalloz, 2014, pp 48-49 (translation Geoffrey Samuel)}

g) Following on from this, formalism can also refer to a certain conception of interpretation of legal texts. 'Interpretative formalism' consists [in the words of $\mathrm{S}$ Castignone] in 'interpreting legal assertions' in a 'logico-systemic mode' in presupposing that one will be able to find in the meaning 'intrinsic in the norm (or system of norms) in question', 'the solution to a legal problem, in bypassing historical, teleological, economic, functional, and environmental factors or, in a word, any facts (which are considered to be) extrinsic'. ...

Thus with codification there was, at least at first, a certain fusing of the mens legislatoris with the verba of the code itself. The role of the jurist was no longer to search for general legal principles in the natural law, for 
they were now inherent in the texts of positive law. Interpretation and deduction became a 'scientific' exercise in that it was a matter of describing what was inherent in the legislative texts and applying these described norms and principles in a neutral (that is logical) fashion. In other words the hermeneutic (interpretation) dimension to legal reasoning became subservient to the logical process. 'The hermeneutical dimension', writes one jurist about 19th-century German legal thought, 'so essential to the legal science of the [German] historical school, is now only a secondary aspect, inferior and negligible to a true and pure scientific treatment of law' (Jouanjan, 2005, 229). Interpretation was considered, at least during the 19th century, as being too closely associated with factors now regarded extrinsic to law. This kind of attitude may be much less intense today in the civil law world, but it underpins the belief of those who think that the role of the judge can be computerised.

\subsection{COMMON LAWYERS}

In England things were different. The Roman texts had little or no influence in a procedural system where the main decisions, at least up to the 16th century, were taken by juries, for there was a jury in every common law case up until the end of the 19th century (see Samuel, 2014, 5-25). Where the common law was rather similar was in the way that its main focal point before the 19th century was the legal action. Nevertheless, these forms of action were very different to the Roman ones. Before the 18th century legal disputes tended to be about whether the right form of action had been brought.

\section{Doige's Case (1442) YB Trin 20 Hen 6 6,f 34, pl 4 Exchequer Chamber (translation CHS Fifoot)}

Newton CJ: If I bail a certain sum of money to Paston to bail over to Fortescue, now, if Paston, does not do this, he will be liable to me in an action of Account and also in an action of Debt, and it is at my pleasure which I shall bring; but when I have brought the one, the other is extinguished. So in this case here there are two actions, Covenant and Deceit, and so the party may bring Deceit if he wishes ...

Fortescue CJ: Willingly. I would agree that, if I buy a horse from you, now the property in the horse is in me, and for this you shall have a writ of Debt for the money and I shall have Detinue for the horse on this bargain. But that is not so in our case. For, though the plaintiff has a right to have his land in conscience, yet the land does not pass without livery. ... 
One might note how the problem of the sale and purchase of a horse is not being analysed in terms of a contract (contract of sale), as would be the case in a system governed by a law based on the Roman model. The case is analysed in terms of the remedies available to the seller of the horse (action in debt) and to the buyer (action in detinue). If a person made a promise which he later did not keep, this might give rise to an action for damages in covenant or deceit (later in a form of action known as assumpsit, an offshoot of trespass). This emphasis on the forms of action continued right up to the 19th century.

\section{Michael Lobban, The Common Law and English Jurisprudence 1760-1850, Oxford University Press, 1991, p 9}

At the beginning of the eighteenth century, most common lawyers did not seek to put their law into a rational form. Because they saw the law as a form of reasoning working within a set of remedies, most legal texts were written not in a systematic way, but as lists. The literature of the common law built from the bottom up, describing what law existed and assuming that it had an internal logic. The common law was seen to be based on the procedure of writs and actions as opposed to substantive laws or rights, so that the law was not seen as a self-contained whole, but developed in response to problems arising in society. Works outlining the various forms of writs were therefore a very important part of common law literature, ... Early eighteenth-century legal literature was dominated by the practitioners' books which displayed precedents of pleas. Such books did not attempt to describe legal rules for the practitioner for 'rules' followed cases, not vice-versa - but neither did they attempt to analyse procedural rules. Instead, they merely showed the correct means with which to present a legal case, recording the pleas and the record of the averments in various cases without looking at all at the legal rules involved, the verdicts given, or the arguments of counsel. They were merely guides on how to draw up a good plea, for if the plea was correctly drawn, the case would be won ...

It was only during the 19th century that English lawyers started to see things in terms of contracts and torts. Indeed even as late as 1840 the law student learned the law by starting out from the actio (as the Romans called it).

Richard Garde, Analysis of Pleading, Maxwell, 1841, pp 1, 3-4

1. An action is the legal demand of a person's right. ...

4. Personal actions are those which are brought for the specific recovery of goods and chattels - or for damages, or other redress, for breach of contract, or other injuries of whatever description, except the recovery of lands, \&c. ... 
14. In personal actions, the most usual of which are assumpsit, debt, covenant, detinue, trespass, trespass on the case, trover, and replevin, the action in the inferior courts must be commenced by a writ of summons or a writ of capias ...

17. Action of debt lies where a person claims the recovery of a certain sum of money alleged to be due to him, and is generally founded on some contract alleged to have taken place between the parties, or on some matter of fact from which the law implies a contract between them.

18. Action of covenant lies where a party claims damages for breach of covenant, ie of a promise under seal.

19. Action of detinue lies where a party claims the specific recovery of goods and chattels or deeds and writings detained from him.

20. Action of assumpsit lies where a party claims damages for a breach of simple contract, ie a promise not under seal. These promises may be expressed or implied, and the law always implies a promise to do that which a party is legally liable to perform.

21. Action of trespass lies where a party claims damages for a trespass, ie an injury committed with violence against him, and this violence may be either actual or implied.

22. Action of trespass on the case lies where a party sues for damages for any wrong or cause of complaint to which covenant or trespass will not apply.

23. Action for trover lies to recover goods and chattels, and in its form it claims damages for these goods and chattels found and converted to the defendant's own use ...

It might be tempting to think that this form of reasoning founded on the actio has disappeared. However, care must be taken. We shall see that there is a remedies model of reasoning which is still very relevant (see 3.5). This said, in 1852 the forms of action were abolished (Common Law Procedure Act 1852 s 3) and this left the common law without its traditional structure. One might note also how Garde linked actions with the notion of a right.

\section{Bryant v Herbert (1877) 3 CPD 389 Court of Appeal}

Bramwell LJ: ... [The Common Law Procedure Acts 1852-1860] did not abolish forms of action in words. The Common Law Commissioners recommended that: but it was supposed that, if adopted, the law would be shaken to its foundations; so that all that could be done was to provide as far as possible that, though forms of actions remained, there never should be a question what was the form. This was accomplished save as to this very question of costs in actions within the county court jurisdiction. Until the passing of the statute [County Courts Act] we are discussing, it was necessary to see if an action was assumpsit, case \&c. But the Common Law Procedure Act having passed, and the forms of actions being practically abolished, the legislature pass this Act dropping the words 'assumpsit, case', \&c., and using the words 'founded on contract', 'founded on 
tort'. This shows to me that the substance of the matter was to be looked at. One may observe there is no middle term; the statute supposes all actions are founded either on contract or on tort. So that it is tort, if not contract, contract if not tort ...

As a result of the abolition of the forms of action the common lawyers looked to the civil law for inspiration. It is not that the judges regarded French or German law as directly applicable to England. They thought that the civil law provided a science of law that transcended particular national states; in other words the great concepts of law such as ownership, possession, contract and fault liability were as relevant to England as to any continental country. This thinking was equally encouraged by the appearance of textbooks on the law of contract during the 19th century. Today, therefore, the taxonomy of the law has changed, although some of the old forms of action have survived as 'causes of action'.

\subsection{LEGAL REASONING IN THE COMMON LAW}

As for legal reasoning itself, there were two sources. There were sources within the law and sources outside of it.

\section{Michael Lobban, The Common Law and English Jurisprudence 1760-1850, Oxford University Press, 1991, pp 80-82}

There were two types of legal argument used by the courts, often concurrently, in solving these cases. One was the form of argument internal to the law, where judges argued from precedents, analogies, and forms, in their desire to articulate the true 'law', and where they urged the need for stability and certainty in law. The second type was external to the law, for the courts held that, where a case had been sufficiently alleged, the courts could rule from the grounds of fitness and justice alone. It was not unusual for judges to make comments like '[c]ommon sense is sufficient to decide this case, without having recourse to any legal decisions on the subject'. For ultimately, the common law was a system of remedies, to correct any wrong, to adjudicate in the best manner for society and the litigants ...

There is a temptation to view the notion of precedent as being as old as the common law itself. This is misleading because up until the 16th century the most important decisions were taken, in the common law courts, by the jury, who did not give reasons for their verdicts. Judges, 
for their part, were really only concerned as to whether the right form of action had been chosen (see generally Baker, 2003).

\section{Henderson v Merrett Syndicates Ltd [1995] 2 AC 145 House of Lords}

Lord Goff: ... The situation in common law countries, including of course England, is exceptional, in that the common law grew up within a procedural framework uninfluenced by Roman law. The law was categorised by reference to the forms of action, and it was not until the abolition of the forms of action by the Common Law Procedure Act 1852 ( 15 \& 16 Vict c 76) that it became necessary to reclassify the law in substantive terms. The result was that common lawyers did at last separate our law of obligations into contract and tort, though in so doing they relegated quasi-contractual claims to the status of an appendix to the law of contract, thereby postponing by a century or so the development of a law of restitution. Even then, there was no systematic reconsideration of the problem of concurrent claims in contract and tort. We can see the courts rather grappling with unpromising material drawn from the old cases in which liability in negligence derived largely from categories based upon the status of the defendant. In a sense, we must not be surprised; for no significant law faculties were established at our universities until the late 19th century, and so until then there was no academic opinion available to guide or stimulate the judges ...

So if one poses the question as to 'what legal reasoning has been' in the English courts, the answer is that, up until the 18th century, it was largely concerned with the boundaries of each form of action - or, more generally, if the right procedure had been followed. Furthermore, as there were no law faculties teaching the common law until the 19th century, there was no corps of professors writing books similar to those of the Roman or medieval jurists. Equally there were no systematisers until Sir William Blackstone (1723-1780), and his great Commentaries had little effect on practitioners.

\section{J Gordley, Contract in Pre-commercial Societies and in Western History, International Encyclopedia of Comparative Law, Volume VII, Chapter 2 \\ (footnotes omitted)}

22. ... Another difference was that the Roman jurists addressed questions of substantive law without enmeshing them in questions of procedure. The English judges did not, in part because originally Common Law courts were not courts of general jurisdiction but heard only those cases brought before them by the King's writ. To receive a remedy the plaintiff had to fit his case within one of the forms of action on which he could bring a writ. Common Law became organised around writs rather than around types of obligations such as contract or tort. 
Thus even in the late 18th century, English judges did not think in terms of a law of contract. They thought in terms of forms of action such as assumpsit and covenant.

Beginning in the late 18th century, this traditional structure changed dramatically. English law ceased to be the exclusive concern of judges and barristers. Beginning with Blackstone, it became a university subject ... The first treatise on contract law, written by Powell in 1790, was followed by a stream of others.

Moreover, the forms of action were abolished by statute. Supposedly, English judges still gave the plaintiff a remedy only when the traditional forms of action would have entitled him to receive one. But the treatise writers and eventually the judges came to think in terms of a law of contract rather than of covenant and assumpsit. They tried to give this law an intellectual coherence that it has previously lacked. They did so, in part, by trying to sharpen the statement of English law they found in the cases. They did so also by borrowing ideas from continental law books, either to clarify a traditional rule or to solve a problem that the Common Law judges had not addressed ... By the end of the 19th century ... the Common Law had acquired a new doctrinal structure largely by borrowing from the continent ...

The change from a system of forms of action to one of contract and tort engendered a new type of reasoning. Instead of reasoning about the form of a particular claim the judges started to reason applying what might be described as a theory of, say, negligence founded on the behaviour of the defendant.

\section{Letang v Cooper [1965] 1 QB 232 Court of Appeal}

Lord Denning MR: ... The truth is that the distinction between trespass and case is obsolete. We have a different sub-division altogether. Instead of dividing actions for personal injuries into trespass (direct damage) or case (consequential damage), we divide the causes of action now according as the defendant did the injury intentionally or unintentionally. If one man intentionally applies force directly to another, the plaintiff has a cause of action in assault and battery, or, if you so please to describe it, in trespass to the person. 'The least touching of another in anger is a battery,' per Holt CJ in Cole $v$ Turner. If he does not inflict injury intentionally, but only unintentionally, the plaintiff has no cause of action today in trespass. His only cause of action is in negligence, and then only on proof of want of reasonable care. If the plaintiff cannot prove want of reasonable care, he may have no cause of action at all. Thus, it is not enough nowadays for the plaintiff to plead that 'the defendant shot the plaintiff.' He must also allege that he did it intentionally or negligently. If intentional, it is the tort of assault and battery. If negligent and causing damage, it is the tort of negligence.

This theory approach is particularly evident with respect to contract. 


\section{Foster v Wheeler (1887) 36 Ch D 695 Chancery Division}

Kekewich J: ... Definitions of 'contract' are to be found in the text-books, and I have consulted several of them, including an American one, that of Mr Parsons. They are all founded on, and many of them simply adopt, the definition given by Pothier in part I, ch $1, \sec 1$, of his work on Contracts. This is his definition, which I take from the English translation of Mr WD Evans: 'An agreement by which two parties reciprocally promise and engage, or one of them singly promises and engages to the other to give some particular thing, or to do or abstain from doing some particular act.' Mr Pollock's definition in his work on the same subject slightly differs from this, and is, in my opinion, more complete and more accurate. He defines a contract, or rather an agreement, to be 'an act in the law whereby two or more persons declare their consent as to any act or thing to be done or forborne by some or one of those persons for the use of the others or other of them;' and in commenting on this definition he explains what is intended by an act in the law, saying that it must be on the face of the matter capable of having legal effect and concerned with duties and rights which can be dealt with by a Court of Justice ...

One might note the influence, first, of civil law writers (Pothier) and, secondly, of textbooks. Law is now being stated very much in terms of rules (regulae iuris). Legal reasoning becomes focused, inter alia, around the interpretation and application of a legal rule, often, since the 19th century, one set out in a statute.

\section{Beswick v Beswick [1966] Ch 538 Court of Appeal [1968] AC 58 House of Lords}

Danckwerts LJ (Court of Appeal): ... The definition of 'property' in s 205(1)(xx) 'includes any thing in action, and any interest in real or personal property'. The section replaces $s 5$ of the Real Property Act 1845 and applies to personal as well as real property. The Act of 1845 only applied to real property, and presumably there was some intelligible object in the extension. The new section obviously cannot be confined to covenants running with the land. Why should the section not be taken to mean what it says? There really is no ambiguity. The section says that 'A person may take ... the benefit of ... any agreement over or respecting land or other property, although he may not be named as a party to the conveyance or other instrument'. The section seems to have come as a shock to conventional lawyers who could not believe their eyes, but the section does say that a person not a party can take the benefit of a contract. Faced with the unexpected and unfamiliar there has been a tendency to take a timorous view of the provisions of this section ...

Lord Guest (House of Lords): ... It may be that the draftsman in incorporating the wide definition of 'property' into s 56 had overlooked the result which it would have on the effect of this section by extending it beyond its predecessor. I am constrained to hold that if $s 56$ is to replace the previous law in $s 5$ of the Act of 
1845 , this can only be done by limiting the word 'property' in s 56 to real property and thereby excluding the wide definition of 'property' contained in s 205(1)(xx). The result is that the respondent has, in my view, no right to sue on the agreement of 14th March 1962 in her individual capacity ...

Michael Lobban, as we have seen, explained that traditionally there were two sources of reasoning used in the common law courts. One was internal to the law (precedents) and one external (natural justice, common sense, policy). Today reasoning about causes of action and rules could be said to be forms of reasoning internal to the law. Yet reasoning using sources external to the law is still to be found as we shall see (see 3.3). This said, the precedent system has since the 19th century become much more formalised.

\section{Council of Law Reporting v Att-Gen [1972] Ch 73 Court of Appeal}

Buckley LJ: ... What then does the evidence establish about the need for reliable law reports and the reasons for publishing them? As the uncontradicted evidence of Professor Goodhart makes clear, in a legal system such as ours, in which judges' decisions are governed by precedents, reported decisions are the means by which legal principles (other than those laid down by statutes) are developed, established and made known, and by which the application of those legal principles to particular kinds of facts are illustrated and explained. Reported decisions may be said to be the tissue of the body of our non-statutory law. Whoever, therefore, would carry out any anatomical researches upon our non-statutory corpus juris must do so by research amongst, and study of, reported cases.

Professor Goodhart recalls that Sir Frederick Pollock in his paper entitled The Science of Case Law published in 1882 pointed out that the study of law is a science in the same sense as physics or chemistry are sciences, and that the material with which it is concerned consists of individual cases which must be analysed and measured as carefully as is the material in the other sciences. At about the same time the 'case system' of teaching law was introduced at the Harvard Law School, which has since become generally adopted. Accurate and authoritative law reports are thus seen to be essential both for the advancement of legal education and the proper administration of justice. As Professor Goodhart says: 'Accuracy in The Law Reports is, therefore, as important for the science of law as is the accuracy of instruments in the physical sciences.'

The legal profession has from times long past been termed a learned profession, and rightly so, for no man can properly practise or apply the law who is not learned in that field of law with which he is concerned. He must have more than an aptitude and more than a skill. He must be learned in a sense importing true scholarship. In a system of law such as we have in this country this scholarship can only be acquired and maintained by a continual study of case law. 
I agree with Foster $\mathrm{J}$ in thinking that, when counsel in court cites a case to a judge, counsel is not in any real sense 'educating' the judge, counsel performing the role of a teacher and the judge filling the role of a pupil; but I do not agree with him that the process should not be regarded as falling under the charitable head of 'the advancement of education.' ...

This 'science' would appear to be one founded on case law. But care must be taken today. The 'case system' at Harvard is, since the American Realists (see 4.1), probably no longer seen as a 'science' akin to the natural sciences; and a question can now be raised as to whether cases, as opposed to statutes, are the primary source of English law.

\subsection{INTERPRETATION OF STATUTES}

The common law has of course traditionally been regarded as being based upon cases and precedents. Before the 19th century this was largely true, but today the position is dramatically different. By far the most important source of law in England is legislation and the great majority of cases decided by the courts involve the interpretation and application of a legislative text. Statutory interpretation is thus central to judging and reasoning in the English courts. However the courts, historically, have the power only to interpret; the judges do not have the constitutional power - as some continental constitutional courts have - to strike down legislation on the grounds that it violates the constitution.

\section{In re K (A Child) [2001] 2 WLR 1141 Court of Appeal}

Judge LJ: ... 119 During the course of the argument I described the submission as 'stunning'. The time we have taken to reflect on our judgments has not diminished my sense of astonishment. In fairness to Miss de Haas I must briefly explain why.

120 If the argument were correct the implementation of the Human Rights Act 1998, on 2 October 2000, would have produced a constitutional earthquake. Parliament would have undermined the principle of parliamentary sovereignty, and revived Sir Edward Coke CJ's dictum in Bonham's Case (1610) 8 Co Rep $114 \mathrm{a}, 118 \mathrm{a}$ that 'the common law will control Acts of Parliament and sometimes adjudge them to be utterly void', a principle identified by Coke in order to impose some fetter on the extravagant royal concept of the prerogative, a controversy eventually settled in this country by the Revolution of 1688. And it would effectively 'set the judicial power above that of the legislature', emphatically described in 1765 by Blackstone in the 1st edition of his Commentaries, some 150 years before universal adult suffrage was established, as 'subversive of all government': BL Com, 1st ed, p 91 (For a still vivid analysis of Bonham's Case 
in its historical context, the relationship of the legislature and the judiciary, and the development of divergent constitutional routes in this country and the United States of America, see T F T Plucknett's article, first published in (1926) 40 Harv L Rev 30, 'Bonham's Case and Judicial Review', in Studies in English Legal History (1983), ch 14.)

121 It may on another occasion be appropriate to examine whether the sovereignty of Parliament empowers it to dispense with or divest itself of its own or any part of its sovereignty, but so far as the Human Rights Act 1998 is concerned, this question simply does not arise. Neither this nor any other court is empowered to repeal or amend, ignore or act contrary to any single statute, or any part of any statute. To the contrary: the Act is carefully drafted to ensure that the court cannot and must not strike down or dispense with any single item of primary legislation.

The rule is that Parliament is supreme and the judges have to apply a statutory provision. Nevertheless they have reserved the power to interpret such provisions. What methods do they employ when doing this?

\section{R (Quintavalle) v Secretary of State for Health [2003] 2 AC 687 House of Lords}

Lord Bingham: ... 8. The basic task of the court is to ascertain and give effect to the true meaning of what Parliament has said in the enactment to be construed. But that is not to say that attention should be confined and a literal interpretation given to the particular provisions which give rise to difficulty. Such an approach not only encourages immense prolixity in drafting, since the draftsman will feel obliged to provide expressly for every contingency which may possibly arise. It may also (under the banner of loyalty to the will of Parliament) lead to the frustration of that will, because undue concentration on the minutiae of the enactment may lead the court to neglect the purpose which Parliament intended to achieve when it enacted the statute. Every statute other than a pure consolidating statute is, after all, enacted to make some change, or address some problem, or remove some blemish, or effect some improvement in the national life. The court's task, within the permissible bounds of interpretation, is to give effect to Parliament's purpose. So the controversial provisions should be read in the context of the statute as a whole, and the statute as a whole should be read in the historical context of the situation which led to its enactment.

Lord Steyn: ... 21. ... The pendulum has swung towards purposive methods of construction. This change was not initiated by the teleological approach of European Community jurisprudence, and the influence of European legal culture generally, but it has been accelerated by European ideas: see, however, a classic early statement of the purposive approach by Lord Blackburn in River Wear Commissioners v Adamson (1877) 2 App Cas 743, 763. In any event, nowadays the shift towards purposive interpretation is not in doubt. The qualification is that the degree of liberality permitted is influenced by the context, eg social welfare legislation and tax statutes may have to be approached somewhat differently ... 
Lord Millett: ... 38. The question is one of statutory construction. In construing a statute the task of the court is to ascertain the intention of Parliament as expressed in the words it has chosen. The Parliamentary intention is to be derived from the terms of the Act as a whole read in its context. Once it has been ascertained, the court must give effect to it so far as the legislative text permits.

39. The search in every case is for what Parliament did intend, not what it would have intended had it foreseen later developments. ..

Two traditional focal points emerge from the common law's view of statutory interpretation: there is the emphasis on the intention of Parliament (mens legislatoris), but this intention is to be gathered primarily from the words used in the statute itself (verba). In other words common lawyers have merged mens legislatoris with the verba. This said, Lord Steyn seems to be suggesting a move towards a functional or purposive approach. Nevertheless it would probably be a mistake to think that a literal approach (verba) has been displaced, as we shall see (see 2.4).

\subsection{LEGACY OF THE PAST}

So what has legal reasoning been? Several models can be induced out of the historical material presented in this chapter. These models will be looked at in more detail in the chapters that follow but they may be summarised as follows:

- Remedies (actio). Early Roman and common law reasoning was centred on the legal action or, to use today's term, remedy. One can talk of a remedies model. In such a model the remedy is seen as the key institution in that it largely forms the subject matter of legal taxonomy (true of both early Roman and common law) and it acts as the starting point for the analysis of litigation facts.

- Rules (regulae iuris). The last title of the Digest is headed de regulis iuris, that is to say it concerns general rules of law (maxims). The Institutes of Justinian also set out the law in terms of general propositions. By the 16th century these regulae iuris had been elevated from mere summaries of the law (the Roman view: D.50.17.1) to a source of law in turn giving rise to the rule model of reasoning. (See further 2.1.)

- Interpretation (interpretatio). An early title (D.1.3) and the penultimate title to the Digest (D.50.16) are devoted (in whole or in part) to the method of interpretation and to the meaning of words. 
There are other extracts also dealing with interpretation. The 16th-century civil lawyers spent much time and energy on the issues surrounding interpretation with the result that this notion of interpretatio became a focal point for reasoning techniques.

- Rights (ius). Later civil lawyers abandoned actions and started to explain law from the position of substantive law (ius) as viewed from the individual - that is to say from the viewpoint of what is ours and what is owed to us. This rights model became another focal point of legal reasoning and was particularly powerful in 20th-century legal thought.

- Policy (utilitas). The Romans never really developed any idea of policy reasoning in the modern sense of the expression, but they did justify some legal propositions on the basis of their utility rather than their strict rationality. It was the common law judges who were prepared to adopt a functionalist approach to decision making and this policy model remains of considerable importance in contemporary common law reasoning.

- Interest (interesse). Another Roman notion that subsequently became a focal point for reasoning was an interest. This expression was used by Roman jurists as a means of determining damage and loss in compensation claims, but in later legal thought it acquired an independence of its own. It became particularly valuable with the development of economics as a discipline since this subject is founded on the notion of interest. Interest provides, then, a valuable bridge between law and economics; yet it is equally an important notion in itself as a descriptive reasoning device.

These focal points - all of which can be traced back to Roman law via the later civilians - do not of course fully explain the complexities of legal reasoning. Far from it. They are simply starting points for thinking about judging; they are what might be called framework models. Reasoning techniques such as induction, deduction and analogy must equally be examined, as must more theoretical orientations such as schemes of intelligibility and paradigm orientations.

\section{FURTHER READING AND QUESTIONS}

1. An excellent overview of the history of civilian legal thought is to be found in Jones (1940) and in Stein (1999). See also Johnston (2015). A more detailed analysis of the reasoning of the civilian jurists is to be found in Gordley (2013). On the 19th century see 
Stein (1980). As for the history of the common law, see Milsom (1981) and Baker (2002). On the 18th and 19th centuries see Lobban (1991). A short introduction to the common law is to be found in Samuel (2013).

2. Did the medieval Roman lawyers (the Glossators and Postglossators or Commentators) reason in an identical way as the Roman jurists or were their methods rather different? (See Berman, 1983, and Gordley, 2013.)

3. Have there been 'revolutions' in the history of legal thought and reasoning? (Cf Maclean, 1992.)

4. When did jurists start to reason in terms of legal rights? (See Jolowicz, 1957, 61-81.)

5. 'It would seem, in fact, that in the seventeenth century, which was a great judicial era, theories of legal classification took very much the place of those theories of law reform which so occupied the minds of the last generation of Englishmen. The continuous activity of legislatures is an altogether modern phenomenon; ... The improvement in view was thus rather a reform of law-books than a reform of law' (Maine, 1890, 362-363). Is this an accurate view of the civil law?

6. Why is it that reasoning in the common law tradition does not seem to have been affected by 16th-century humanist writers? (Cf Baker, 2003.)

7. Did legal reasoning in the common law profoundly change in the 16th century? Did it change in the 19th century? (See Baker, 2003; Lobban, 1991; Ibbetson, 1999.) 